\title{
AC 2008-2359: THE STATE OF ENGINEERING PROGRAM ACCREDITATION AND QUALITY ASSURANCE IN INDIA
}

Krishna Vedula, University of Massachusetts-Lowell

Maria M. Larrondo Petrie, Florida Atlantic University 
Indo US Engineering Faculty Leadership Institute Summer 2008

May 26 to June 13 \& June 30 to July 18,2008

Global Education Center, Infosys Technologies Ltd., Mysore

\section{FACULTY DEVELOPMENT PROGRAMMES}

Offered by

Indo US Collaboration for Engineering Education (IUCEE)

\section{Information Brochure}

\&

\section{Registration Details for Faculty of Engineering Colleges}

Resource Persons

Distinguished faculty from renowned US universities

in association with expert professors from Indian engineering education system

$$
\text { sponsored by }
$$

Desh and Jaishree Deshpande, USA and Sudha and Narayana Murthy, India

in partnership with

American Society for Engineering Education (ASEE), Indian Society for Technical Education (ISTE)

and International Federation for Engineering Education Societies (IFEES)

VENUE: Global Education Center, Infosys Technologies Ltd., Mysore, Karnataka State, India

Registration can be for any number of individual workshops

Fees of Rs. 2,500 for each workshop covers boarding and lodging at venue

Address for Correspondence:

Sri.L.Premachandra Reddy,IAS

Commissioner of Technical Education

5th and 6th Floor, BRK Bhavan, Tank Bund Road, Hyderabad - 500 027, A.P. India

Deadline for receipt of $A P P L I C A T I O N O N-L I N E$ and COMMITMENT FORM BY POST is March $5,2008$. Any questions should be addressed by email to pnpradeep@gmail.com. 


\section{INTRODUCTION}

The Indo-US Collaboration for Engineering Education (IUCEE) is an organization created by leading engineering educators in the US and in India, with the goal of improving the preparedness of the large number of faculty in engineering colleges in India and in the US to address the needs of the global economy. The American Society for Engineering Education (ASEE) and the Indian Society for Technical Education are primary partners. The Action Plan, developed at two Forums, one in Mysore in June 2007 and the second in Washington DC in August 2007, recommended the creation of Regional Indo US Engineering Faculty Institutes with four thrust areas: Curriculum Development, Pedagogy and Delivery; Research and Development; Quality and Accreditation and Innovation and Entrepreneurship, with strong Industry partnership.

These Regional Indo-US Faculty Institutes will foster collaborative networks and exchanges through course offerings for engineering faculty. The resulting networks are expected to lead to mutual benefits to India and to the US, including global experiences for faculty and students, collaborative research, development and entrepreneurship in technologies of global relevance, as well as access for US and Indian universities and companies to more and better prepared engineering graduates.

An Indo US Engineering Faculty Leadership Institute is planned for the summer of 2008 in order to prepare engineering faculty who will lead the creation of these Regional Institutes. Scaling up of the program will be achieved by the "Facilitate the Trainer" approach. Experienced faculty from various regions will be selected to attend the Indo US Engineering Faculty Leadership Institute conducted by US and Indian faculty experts. One week workshops will be offered on specific subjects in close consultation with industry. These workshops will focus on effective methods for teaching the specific subjects and on providing links and access to resources for that purpose. The workshops will be designed to ensure the creation of sustainable communities of practice and collaboration among participants. The workshops will include strategies for mentoring of the selected faculty at their home institutions. They will be encouraged and facilitated to be trainers and will be assisted in offering one-week courses to groups of faculty from engineering colleges at workshops in their regions during the following year as part of their Regional Institutes. They will also be encouraged to conduct workshops to motivate good students in the colleges to enter the teaching profession. In addition, they will be supported in setting up research programs in their colleges, and pursue doctorate degrees (if not already possessing one). A critical part of the program will be the assessment of the outcomes from these in order to guide further development of the programmes. Although the major emphasis in the first year is on computer science and engineering, information technology, telecommunications and electrical engineering, IUCEE plans to cover all disciplines of engineering in subsequent years.

\section{PROGRAMME DETAILS:}

Schedule for "2008 Indo-US Engineering Faculty Leadership Institute" (Location: Global Education Center, Infosys Technologies Ltd., Mysore, India)

\begin{tabular}{|c|c|c|c|}
\hline & Topic & Lead Presenters, Affiliation & Dates \\
\hline 2 & $\begin{array}{l}\text { Effective Teaching; Cooperative Learning; } \\
\text { Effective Faculty Development, } \\
\text { Outcomes based education; Quality and Accreditation } \\
\text { Preparation for India's membership in Washington Accord }\end{array}$ & Rich Felder and Rebecca Brent, N. Carolina State University & $\begin{array}{l}\text { May } 26 \text { to } 28 \\
\text { May } 29 \text { to } 30\end{array}$ \\
\hline 3 & $\begin{array}{l}\text { Curriculum Innovation and Quality Assurance: } \\
\text { a Roadmap for Excellence } \\
\text { \& Building Industry Academia Partnerships }\end{array}$ & $\begin{array}{l}\text { Jorge Velez-Arocho and Rosa Buxeda, Univ of Puerto Rico; } \\
\text { Lueny Morell, Hewlett Packard }\end{array}$ & June 2 to 6 \\
\hline $\begin{array}{l}4 \\
5 \\
6 \\
7\end{array}$ & $\begin{array}{l}\text { Strategies for Effective Course Design and Delivery } \\
\text { Selected Topics in Computer Engineering } \\
\text { Computer Networks } \\
\text { Wireless Communications }\end{array}$ & $\begin{array}{l}\text { Veena Kumar, Rutgers, The State University of New Jersey } \\
\text { Joseph Tront, Virginia Tech University } \\
\text { James Kurose, University of Massachusetts, Amherst } \\
\text { P.R. Kumar, University of Illinois Urbana Champagne }\end{array}$ & $\begin{array}{l}\text { June } 9 \text { to } 13 \\
\text { (Parallel } \\
\text { Workshops) }\end{array}$ \\
\hline $\begin{array}{c}8 \\
9 \\
10 \\
11 \\
12 \\
\end{array}$ & $\begin{array}{l}\text { Signal Processing } \\
\text { Algorithms, Tutored Video Instruction } \\
\text { Software Engineering } \\
\text { Computer Security and Modern Compilation } \\
\text { Principles of Effective Teaching and Learning }\end{array}$ & $\begin{array}{l}\text { Sidney Burrus, Rice University } \\
\text { Richard Anderson, University of Washington } \\
\text { Leon Osterweil and Lori Clarke, Univ of Massachusetts } \\
\text { Jack Davidson, University of Virginia } \\
\text { P.V. Krishnan, GIW Industries, USA } \\
\end{array}$ & $\begin{array}{l}\text { June } 30 \text { to July } 4 \\
\text { (Parallel } \\
\text { Workshops) }\end{array}$ \\
\hline $\begin{array}{c}13 \\
14 \\
15 \\
16 \\
17 \mathrm{~A} \\
17 \mathrm{~B} \\
18\end{array}$ & $\begin{array}{l}\text { VLSI Design } \\
\text { Engineering Design Projects in Service to Community } \\
\text { Project Management; Data Base Design; Security } \\
\text { Electric Energy and Power } \\
\text { Academic Systems and Processes } \\
\text { Engineering Education for Building Knowledge Economies } \\
\text { Focus on Governance } \\
\text { Academic Leadership }\end{array}$ & $\begin{array}{l}\text { Andrew Mason, Michigan State University } \\
\text { William Oakes, Purdue University } \\
\text { Vijay Kanabar, Boston University } \\
\text { S.S. Venkata, University of Washington } \\
\text { M.P. Ravindra, Infosys Technologies Ltd } \\
\text { Andreas Blom, World Bank, } \\
\text { Bruno Laporte, Kurt Larsen, Anuja Utz, World Bank Inst } \\
\text { M.P. Ravindra, Infosys Technologies Ltd }\end{array}$ & $\begin{array}{l}\text { July } 7 \text { to } 11 \\
\text { (Parallel } \\
\text { Workshops) } \\
\text { July } 7 \text { to } 8 \\
\text { July } 9 \text { to } 10 \\
\text { (invited only) } \\
\text { July } 11\end{array}$ \\
\hline $\begin{array}{l}19 \\
20 \\
21 \\
22 \\
23\end{array}$ & $\begin{array}{l}\text { Hands-on Engineering using Labview } \\
\text { Project Based Learning, Sustainable Product Design } \\
\text { Product Life Management using CAD } \\
\text { Developing Leadership Skills } \\
\text { Engineering Drawing using CAD }\end{array}$ & $\begin{array}{l}\text { Dhanabal Solaikutty, National Instruments } \\
\text { Alice Agogino, University of California, Berkeley } \\
\text { Xavier Fouger, Dassault Systemes } \\
\text { Zacharias Cherian, Agilent Technologies, India } \\
\text { George Abraham, Autodesk }\end{array}$ & $\begin{array}{l}\text { July } 14 \text { to } 18 \\
\text { (Parallel } \\
\text { Workshops) } \\
\text { July } 17 \text { to } 18 \\
\text { July } 14 \text { to } 18\end{array}$ \\
\hline
\end{tabular}


Workshops are for one week (five days) unless otherwise specified. For the content workshops (\# 5 to 11 ; \# 13 to 16 ; \#19 to 21 ), typically the first 3 or 4 days of the week will cover the curriculum, pedagogy and effective teaching of relevant courses and the rest of the time will be devoted to latest trends in research in that topic. All workshops are independent of each other. Participants can attend any number of workshops they desire, if selected. There are no workshops from June 14 to June 29.

\section{3. $\quad$ FINANCIAL SUPPORT}

IUCEE acknowledges the support of their primary sponsors: Jaishree and Desh Deshpande (Founder, Sycamore Networks, US) and Sudha and Narayana Murthy (Co-Founder, Infosys Technologies, India). This support covers expenses for resource persons from US and India, development of course materials, arrangements for participants at Mysore and administrative costs. The regional follow up of the workshops at the Regional Indo US Engineering Faculty Institutes is expected to be supported by regional colleges, state government agencies, central government agencies and businesses.

\section{4. $\quad$ LIMITATIONS ON NUMBER OF PARTICIPANTS}

Participants may apply to attend any number of workshops as they desire. For each content specific workshop (\# 5 to 11 ; \# 13 to 16; \# 19 to 21), a maximum of 30 participants will be selected from among faculty applicants from all states in India. For the workshops which cover general teaching and learning concepts a maximum of 100 participants each will be selected for \# 1 and \# 3, while \# 4 and \# 12 will be limited to 30 participants each. Workshop \# 17A and \# 17B on "Academic Systems \& Processes" and "Governance" are designed primarily for heads of institutions and policy makers and participation is by invitation only. Workshops \# 18 and 22 on leadership skills will be limited to 30 participants by invitation only.

\section{5. $\quad$ FEES TO BE CHARGED}

Participants will be charged fees of Rs. 2,500 ( \$ 65) for each one week workshop in order to cover some minimum costs and to ensure seriousness of the participants. This will cover boarding and lodging at the Global Education Center of Infosys Technologies at Mysore. A 50 \% discount on fees will be offered to qualified and selected women participants. Participants are expected to provide for their travel to come to Mysore using funds from other sources. (The real cost is estimated at Rs. 40,000 for a participant attending a one week workshop. Participants are being charged only a nominal amount this year)

\section{6. $\quad$ THE APPLICATION PROCESS}

Potential participants must complete an on-line application form available at http://iucee.org/ . Participants are encouraged to enroll for one of the effective teaching workshops (\# 1,3,4 or 12) as well as one or more of the content specific workshops \# 5 -11 and \# 13 -16 and \# 18 - 21). Applicants need to download the commitment form from the website, complete the section on their own commitment as well as obtain the written undertaking from the head of their institution. The completed commitment form should be posted to the address provided. Deadline for receipt of application on-line and commitment form by post is March 5, 2008. Any questions should be addressed by email to pnpradeep@gmail.com. Please let us know if you have any special needs, such as handicapped facilities.

\section{QUALIFICATIONS AND EXPERIENCE OF PARTICIPANTS}

Applicants must have plans to continue in the teaching profession. Applicants holding Master's degrees will be given preference for selection as participants in the above summer workshops. Applicants should have at least one years experience in teaching, although preference will be given to those with more teaching experience. Special consideration will be given to women faculty, even if they are temporarily not teaching. Of particular importance will be the potential for participants to be leaders of engineering education in their region.

\section{SELECTION OF PARTICIPANTS}

Applications will be reviewed by a selection committee. Applicants will be selected based on their qualifications and potential to be leaders in their region. (After preliminary screening, some of the suitable applicants may be sent a "Questionnaire" to ascertain the attitudes and motivation of the applicant as well as their plans to carry the effort forward in their regions, prior to final selection). Selected applicants will be confirmed for participation and will be instructed regarding payment of fees.

\section{SELECTION AND CERTIFICATION OF TRAINERS FOR REGIONAL INSTITUTES}

Since a vital part of the IUCEE Action Plan is to create Regional Indo US Engineering Faculty Institutes, several of participants from each of the above workshops will be selected and certified as Trainers for the Regional Institutes. These Trainers will be coached and certified to offer similar workshops in their regions later. Selection of Trainers will be based on qualifications, experience as well as performance in the summer workshops. Selected and certified Trainers will be provided opportunities for further professional development including guidance to Ph.D. programs, where appropriate. All participants 
will be awarded certificates and one course credit per workshop completed satisfactorily, towards a planned diploma in engineering education (details of diploma are not yet decided).

\section{COMMITMENTS FROM PARTICIPANTS}

Participating faculty are expected to prepare for the workshops before hand using materials to be provided. All participating faculty will be expected to complete projects based on the workshop/s attended and assess outcomes in the relevant courses they teach during the following semester. Participants selected to be Trainers will be expected to offer at least one workshop in their own region (in the following Fall semester or Spring semester). All participants will be expected to conduct one workshop in their region for attracting high quality students to enter the teaching profession. A report on the outcomes of these workshops will be expected by IUCEE, in the format to be specified.

\section{1. $\quad$ COMMITMENTS FROM INSTITUTIONS}

Institutions to which the faculty participants belong, will be required to commit to encouraging and supporting participating faculty in fulfilling their commitments as described above. In particular, for institutions from which Trainers are selected, the Institutions are expected to provide facilities and support for conducting regional workshops.

\section{BENEFITS OF PARTICIPATION}

Participating institutions and faculty will benefit by becoming identified as leaders of high quality engineering education. Industry partners of IUCEE and leading US universities and Indian universities will give priority for student recruitment from and collaborations with institutions participating in IUCEE programmes and demonstrating leadership in conducting regional workshops and creating regional institutes.

\section{Organization of IUCEE}

\section{Partners}

All India Council for Technical Education (AICTE)

International Federation of Engineering Education Societies (IFEES)

Indian Society for Technical Education (ISTE)

MIT Open Course Ware (OCW)

Indo-US Collaboration via EDUSAT

Indian National Academy of Engineering (INAE)

Governance and Leadership (to be finalized)

Patrons and Honorary $\mathrm{C}_{0}$-Chairs

Desh Deshpande; Jaishree Deshpande;

Narayana Murthy; Sudha Murthy;

Executive Committee

Frank Huband, Executive Director, ASEE

Satish Udpa, Dean, Michigan State University

Ashok Saxena, Dean, University of Arkansas

Gretchen Kalonii, Internl Programs, Univ of CA

Lueny Morell, University Relations, HP

James Melsa, President, ASEE (ex officio)

Satish Kulkarni, US Embassy in India

Michael Cheetham, Director, ISTP

\section{Advisors}

Paul Peercy Dean, University of Wisconsin

Barbara Olds, Assoc VP, Colorado School of Mines

Jack Lohmann, Vice Provost, Georgia Inst of Tech

Bruno Laporte, World Bank Institute

Vijay Kumar, Sr. Associate Dean, MIT

S. S. Venkata, University of Washington

Raghu Raghavendra, Assoc Dean, USC

Teri Reed-Rhoads, Assoc Dean, Purdue Univ

Xavier Fouger, Dassault Systemes

Ravi Marawar, National Instruments

Kalyan Vaidyanathan, Manager, i2 Technologies

M.A. Pai, University of Illinois, Urbana Champagne

Krishna Athreya, lowa State University

Satish Tripathy, Provost, SUNY Buffalo

Anjan Bose, Professor, Washington St. Univ

Sponsors;

Sponsors for 2008 Leadership Institute

Sponsors for 2007 Action Planning Forums

Indo US Science and Technology Forum

\author{
Department of Science and Technology (DST) \\ Global Pan IIT \\ Accreditation Board for Engineering and Technology (ABET) \\ Connexions at Rice University \\ National Science Foundation (NSF) \\ Industry groups: CII, FICCI, NASSCOM, HYSEA \\ Indo US Science and Technology Forum (IUSSTF) \\ Technical Education Quality Improvement Program (TEQIP), \\ Infosys Campus Connect \\ National Program for Technology Enhanced Learning (NPTEL) \\ National Academy of Engineering (NAE) \\ Board of IT Education Standards (BITES)
}

Executive Director: Krishna Vedula, University of Massachusetts

Associate Director (India): P.S. Grover, Guru Tegh Bahadur Institute of Technology

Executive Advisor: Hans J. Hoyer, Director International Programs ASEE

R. Natarajan, Former Chairman, AICTE

N. Balakrishnan, Associate Director, Indian Institute of Science

AICTE Chairman (to be appointed)

Sanjay Dhande, Director, IIT Kanpur

M. P. Ravindra, Advisor, Infosys Technologies

N. R. Shetty, President, ISTE (ex officio)

Arabinda Mitra, Executive Director, IUSSTF

P. Narasimha Reddy, Director, Sri Nidhi Institute of Technology

Venkat Rangan, Vice Chancellor, Amrita University

L. K. Maheshwari, Vice Chancellor, BITS Pilani

M. S. Ananth, Director, IIT Madras.

Damodar Acharya, Director IIT Kharagpur

Deepak Bhatnagar, TIFAC-CORE, DST

Dhrubes Biswas, IIT Kharagpur

K. Rajagopal, Vice Chancellor, JNTU, AP

H. P. Khincha, Vice Chancellor, VTU, Karnataka

Venkatesh Valluri, MD, Agilent Technologies India

P. Anandan, MD. Microsoft India

Anil Jampala, HYSEA

S. Chatterjee, Advisor, DST, Govt. of India

Kaushik Mukherjee, Secretary, Government of Karnataka

Madan Padaki, CEO, Merit Trac

Sandeep Sancheti, Director, NIT Suratka

Vinnie Jauhari, Hewlett Packard India

Jaishree and Desh Deshpande

Sudha and Narayana Murthy

Indo US Science and Technology Forum

Infosys Technologies

Jaishree and Desh Deshande

Infosys Technologies

Dassault Systemes 


\section{APPLICATION FORM}

(to be completed and submitted on line by applicant; available at http://iucee.org/)

I Select Courses:

\begin{tabular}{|c|c|c|c|c|}
\hline $\begin{array}{l}\text { SI. } \\
\text { No. }\end{array}$ & Select & Topic & Constraints & Dates \\
\hline 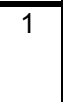 & & $\begin{array}{c}\text { Effective Teaching; Cooperative Learning; } \\
\text { Effective Faculty Development, } \\
\text { Outcomes based education; Quality and Accreditation }\end{array}$ & None & May 26 to 28 \\
\hline 2 & & Preparation for India's membership in Washington Accord & None & May 29 to 30 \\
\hline 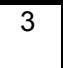 & & $\begin{array}{c}\text { Learning Factory, Effective Teaching; Continuous Quality Assurance } \\
\text { Building Industry Academia Partnerships }\end{array}$ & None & June 2 to 6 \\
\hline 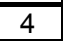 & & Strategies for Effective Course Design and Delivery & None & June 9 to 13 \\
\hline 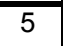 & & Computer Engineering & None & June 9 to 13 \\
\hline 6 & & Computer Networks & None & June 9 to 13 \\
\hline 7 & & Wireless Communications & None & June 9 to 13 \\
\hline 8 & & Signal Processing & None & June 30 to July 4 \\
\hline 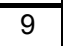 & & Algorithms, Tutored Video Instruction & None & June 30 to July 4 \\
\hline 10 & & Software Engineering & None & June 30 to July 4 \\
\hline 11 & & Computer Security and Modern Compilation & None & June 30 to July 4 \\
\hline 12 & & Principles of Effective Teaching and Learning & None & June 30 to July 4 \\
\hline 13 & & VLSI Design & None & July 7 to 11 \\
\hline 14 & & Engineering Design Projects in Service to Community & None & July 7 to 11 \\
\hline 15 & & Project Management; Data Base Design; Security & None & July 7 to 11 \\
\hline 16 & & Electric Energy and Power & None & July 7 to 11 \\
\hline 17 & & $\begin{array}{c}\text { Engineering Education for Building Knowledge Economies } \\
\text { Focus on Governance }\end{array}$ & Invited Only & July 9 to 10 \\
\hline 18 & & Academic Leadership & None & July 11 \\
\hline 19 & & "Hands-on Engineering using Labview & None & July 14 to 18 \\
\hline 20 & & Project Based Learning, Sustainable Product Design & None & July 14 to 18 \\
\hline 21 & & Product Life Management using CAD & None & July 14 to 18 \\
\hline 22 & & Developing Leadership Skills & None & July 17 to 18 \\
\hline
\end{tabular}

II Name of Applicant:

Institution currently with:

Email ID:

III Qualifications:
Date of Birth:

City and State:

Mobile Number:

\begin{tabular}{|l|l|l|l|}
\hline Name of Degree & Specialization & Division & Any Honours \\
\hline & & & \\
\hline & & & \\
\hline & & & \\
\hline
\end{tabular}


IV Experience:

\begin{tabular}{|c|c|c|c|}
\hline Institute & From & To & Any Distinctions \\
\hline & & & \\
\hline & & & \\
\hline & & & \\
\hline
\end{tabular}

V Subjects Taught in Past 2 Years:

\begin{tabular}{|l|l|l|}
\hline Name of Subject & Branch & UG/PG \\
\hline & & \\
\hline & & \\
\hline & & \\
\hline
\end{tabular}

V Research Experience:

Number of Papers published in Subject Area

If you do not have a Doctorate degree, are you Registered for Ph.D.

If are not registered for Ph.D., do you wish to register for Ph.D.

If you are a Doctorate already, do you wish to continue research

VI Address for Correspondence:

Deadline for receipt of on-line application and commitment form by post is March 5, 2008.

Any questions should be addressed by email to pnpradeep@gmail.com. 
Indo US Engineering Faculty Leadership Institute

Summer 2008, Infosys Technologies, Mysore

\section{COMMITMENT FORM}

(to be completed by applicant as well as head of institution and posted to address given below)

Part A: $\quad$ Commitment of Faculty Member:

As a participant, I hereby undertake to use my training in the summer workshop to improve the quality of my teaching in at least one course in the following semester and assess the outcomes according to the Assessment Process prescribed by IUCEE. I also undertake to conduct one workshop for high quality students in my region, in order to motivate them to pursue teaching careers.

If selected as a Trainer, I hereby undertake to use my training in the summer workshop to conduct atleast one workshop on the same subject for faculty in my region, and assess the outcomes according to the Assessment Process prescribed by IUCEE. I also undertake to assist in building a research program in my college.

Date: Name: Signature:

Designation: Institution:

Part B: $\quad$ Undertaking of Institution:

Our Institute which is sponsoring Mr/Dr (Designation) hereby undertakes to provide appropriate support to him/her for fulfill commitments and give any infrastructural and financial support to him/her to conduct atleast one workshop in our region if he/she is selected to be a Trainer.

Date: Name: Signature;

Rubber Stamp

Designation of Signatory:

Institution:

Address:

Signatory: email

mobile number

Completed Commitment Form should be posted to:

Sri. L. Premachandra Reddy,IAS

Commissioner of Technical Education

5th and 6th Floor, BRK Bhavan, Tank Bund Road,

Hyderabad - 500 027, A.P. India 
"IUCEE 2008 Summer Workshops" should be written on the Envelope

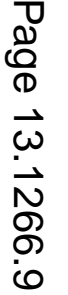

